\title{
Tony Lawson's The Nature of Social Reality: Issues in Social Ontology: A Review
}

\section{Josef Menšík ${ }^{1}$}

The latest book of Tony Lawson, University of Cambridge professor of economics and philosophy, addresses fundamental issues pertaining to philosophy and methodology of economics, and social science in general, he has been investigating since early 1990'. The Nature of Social Reality: Issues in Social Ontology (Routledge, 2019) is another fruit of Tony Lawson's persuasion that there is a serious structural failure concerning 'practices bound up with social theorising in the academy,' and that 'practices of systematic and sustained reasoning about the nature of the social world, explicitly pursued, need to be recovered from the margins.' Lawson's life-long project stems from his identification of an extensive gap at the foundations of present social theorising, in mainstream economics in particular, which leads to ill-guided research programmes, unsound and weakly grounded theoretical results, and general 'gross misallocation of resources' within large parts of present academia. Lawson has devoted his academic career to filling up the said gap by providing the missing foundations for social science by pursuing an explicit research into the nature and structure of social reality - social ontology.

The Nature of Social Reality contains both elaborations of the general socio-ontological conceptions of Lawson as well as their applications to particular domains of economic theory and social theory at large. Written as a series of a stand-alone chapters, the book may well serve both as a handy introduction to Lawson's conception of social ontology, as well as the record and source of some of the most developments, ramifications and applications of the approach welcomed by the experts in the area. I this context, I want to draw the attention of the more selective readers especially to the opening parts of the more applied chapters which, as a rule, continue a short summary and, sometimes, reformulations and advancements of Lawson's general position.

The eight-chapter book is half composed of original material, the other four chapters being republications of recent important papers, some of them less easily accessible. Chapters 1, 2 and 7 are devoted to the exposition of Lawson's general approach in social ontology and the elaboration of some of its key ideas, such as social positioning, social relations, social roles, rights and obligations, the role of trust, collective practices, emergence, communities as structural emergents, being among the most notable. In chapters 3 and 4, considering the nature of (present) corporation, Lawson is setting up an original framework for the debate of the role of corporations in present society, perhaps even reconsideration of their legal status. Chapters 4 and 6 are the two most recent

\footnotetext{
${ }^{1}$ Masaryk University, Faculty of Economics and Administration, Department of Economics, Lipová 41a, Brno, 602 00, Czech Republic. E-mail: mensik@ mail.muni.cz.

(C) 2020 by the authors; licensee Review of Economic Perspectives / Národohospodárský obzor, Masaryk University, Faculty of Economics and Administration, Brno, Czech Republic. This article is an open access article distributed under the terms and conditions of the Creative Commons Attribution 3.0 license, Attribution - Non Commercial - No Derivatives.
} 
in the line of Lawson's contributions to the present debate on the nature of money. Chapter 8 contains his ideas in political philosophy and ethics.

The hub of Lawson's socio-ontological position is the society (or community) considered as a structured emergent totality composed of social positions bound together by mutual laws and obligations, which are being constantly formed and reformed within the reproductive process of collective practices. Applying this framework on the (business) corporation Lawson, after re-examining its historical development, reconsiders the position and the associated rights and obligations this artificial legal person enjoys. For money, Lawson proposes his own alternative to the credit and debt theories of (the nature of) money: the positioning theory of (successfully functioning) money, which shows some similarities with the older state theory of money or the present modern monetary theory. Lawson's politico-philosophical and ethical ideas are centred around the conception of human flourishing, and the feasibility of its attainment via the removal of political and legal obstacles hindering its progress.

Although not every reader will agree with all the details and applications into political philosophy, monetary theory and legal theory of Lawson's general approach he provides in this book, those more applied chapters are, nevertheless, full of inspiration and general interest, and worth reading for anybody. The more abstract chapters, on the other hand, provide a rare summary and exposition of one of the world leading approaches in social ontology at present. As such, they are a must for everybody even vaguely interested in such questions as: what is the nature and structure of social reality, how should social science (and economics in particular) be grounded, what sort of results (laws, models, predictions) are we to suppose in social science. 